Neuroepidemiology 2012;39:176

DOI: $10.1159 / 000342176$

\section{Validation of the Prolonged Length of Stay Score in the Dijon Stroke Registry}

\section{Yannick Béjot, Corine Aboa-Eboulé, Maurice Giroud}

Dijon Stroke Registry, EA4184, University Hospital and Medical School of Dijon, University of Burgundy, Dijon, France

Since length of stay (LoS) is a major contributor to hospital costs in stroke patients [1], tools to predict LoS would help care providers to determine the need for medical provisions. The Prolonged Length of Stay (PLOS) score was developed from the National Acute Stroke Israeli Survey 2004 study [2], and includes 5 independent predictors of PLOS defined as $\geq 7$ days of hospitalization. Each dichotomous predictor (intracerebral hemorrhage, decreased level of consciousness, history of congestive heart failure, and prior atrial fibrillation) adds 1 point. Additionally, stroke severity assessed by the National Institutes of Health Stroke Scale (NIHSS) contributes 2 points, 3 points and 1 point, respectively, with a NIHSS score of $6-10,11-20$, and $>20$. Although the PLOS score was successfully validated in the National Acute Stroke Israeli Survey 2007 study [2], and the Oxford Vascular Study [3], external validation in populations with different case mixes and care policy is required.

We aimed to evaluate the performance of the PLOS score in acute stroke patients in France. Data of consecutive patients, with either first-ever or recurrent ischemic stroke and intracerebral hemorrhage hospitalized from 1st January 2006 to 31st December 2010 were retrieved from the population-based stroke registry of Dijon $[4,5]$. Individual PLOS scores (range $=0-7$ ), median LoS [interquartile range (IQR)], and distribution of $\operatorname{LoS} \geq 7$ days by PLOS score were calculated. Analyses were performed for all inpatients and hospital survivors only. The c-statistic, representing the area under the receiver operating characteristic curve, was evaluated. Observed and predicted rates of PLOS by score category were compared with the Hosmer-Lemeshow goodness-of-fit test. Statistical analysis was performed with STATA ${ }^{\circledR} 10.0$ software (StataCorp LP, College Station, Tex., USA).

Among the 999 recorded patients, the PLOS score was available for 880 (88.1\%). The median LoS was 13 (IQR =6-23) in inpatients and 13 (IQR =7-22) in survivors. The median LoS and proportion of patients with $\operatorname{LoS} \geq 7$ days by the PLOS score are shown in table 1. For inpatients, the model showed poor discrimination (c-statistic $=0.62,95 \% \mathrm{CI}=0.58-0.67$ ) and the HosmerLemeshow test showed significant differences between predicted and observed rates $(\mathrm{p}=0.02)$. For survivors, moderate discrimination was found (c-statistic $=0.68,95 \% \mathrm{CI}=0.64-0.72)$ with a nonsignificant Hosmer-Lemeshow test $(\mathrm{p}=0.09)$. No more convincing results were obtained when PLOS was defined as $\geq 30$ days (c-statistic $=0.67,95 \% \mathrm{CI}=0.63-0.71$ for overall patients; $\mathrm{c}$-statistic $=0.69,95 \% \mathrm{CI}=0.64-0.73$ for survivors; $\mathrm{p}=0.01$ and $\mathrm{p}=0.03$, respectively, for Hosmer-Lemeshow test).
Table 1. Median LoS and proportion of patients with $\operatorname{LoS} \geq 7$ days by PLOS score

\begin{tabular}{|c|c|c|c|c|c|c|}
\hline \multirow{2}{*}{$\begin{array}{l}\text { PLOS } \\
\text { score }\end{array}$} & \multicolumn{3}{|c|}{ All hospitalized patients $(n=880)$} & \multicolumn{3}{|c|}{ Hospital survivors $(\mathrm{n}=751)$} \\
\hline & $\mathrm{n}$ & $\begin{array}{l}\text { median LoS } \\
\text { days }\end{array}$ & $\begin{array}{l}\text { LoS } \geq 7 \text { days } \\
n\end{array}$ & $\mathrm{n}$ & $\begin{array}{l}\text { median LoS } \\
\text { days }\end{array}$ & $\begin{array}{l}\operatorname{LoS} \geq 7 \text { days } \\
\mathrm{n}\end{array}$ \\
\hline 0 & 261 & $8(5-14)$ & $157(60.2)$ & 257 & $8(5-14)$ & 154 (59.9) \\
\hline 1 & 140 & $13(7-22.5)$ & $112(80.0)$ & 124 & $13(7.5-20.5)$ & $101(81.5)$ \\
\hline 2 & 187 & $14(7-28)$ & $148(79.1)$ & 152 & $15(8-27.5)$ & $129(84.9)$ \\
\hline 3 & 170 & $17(9-30)$ & $140(82.4)$ & 132 & $17(10-30.5)$ & $115(87.1)$ \\
\hline 4 & 91 & $17(8-30)$ & $73(80.2)$ & 67 & $20(11-30)$ & $60(89.6)$ \\
\hline 5 & 28 & $19(12-34.5)$ & $24(85.7)$ & 19 & $18(11-35)$ & $17(89.5)$ \\
\hline$\geq 6$ & 3 & $13(2-33)$ & $2(66.7)$ & 0 & - & - \\
\hline
\end{tabular}

Figures in parentheses indicate IQRs or percentages.

Our results suggest that the PLOS score was neither a good predictor of $\operatorname{LoS} \geq 7$ days nor of $\operatorname{LoS} \geq 30$ days, although it worked better for survivors. This contrasts with previous results [2,3]. One possible explanation may be the greater median LoS in our population, compared with previous studies. The proportion of patients with $\operatorname{LoS} \geq 7$ days ranged from $60 \%$ for patients with a PLOS score $=0$ to approximately $80 \%$ in other categories except for a PLOS score $\geq 6$ (only 3 patients, interpretation therefore limited).

The PLOS score seems valid in health systems with a short median LoS for stroke patients, but is less useful in those with long LoS. As LoS depends on several factors, including accessibility of diagnostic resources and availability of postacute facilities [5], our findings indicate that the PLOS score requires validation in other populations before generalization.

\section{Disclosure Statement}

The authors declare no conflicts of interests.

\section{References}

1 Diringer MN, Edwards DF, Mattson DT, Akins PT, Sheedy CW, Hsu CY, Dromerick AW: Predictors of acute hospital costs for treatment of ischemic stroke in an academic center. Stroke 1999;30:724-728.

2 Koton S, Bornstein NM, Tsabari R, Tanne D, NASIS Investigators: Derivation and validation of the prolonged length of stay score in acute stroke patients. Neurology 2010;74:1511-1516.

3 Koton S, Luengo-Fernandez R, Mehta Z, Rothwell PM: Independent validation of the prolonged length of stay score. Neuroepidemiology 2010;35:263-266.

4 Béjot Y, Aboa-Eboulé C, Durier J, Rouaud O, Jacquin A, Ponavoy E, Richard D, Moreau T, Giroud M: Prevalence of early dementia after first-ever stroke: a 24-year population-based study. Stroke 2011;42:607-612.

- 5 Béjot Y, Troisgros O, Gremeaux V, Lucas B, Jacquin A, Khoumri C, Aboa-Eboulé C, Benaïm C, Casillas JM, Giroud M: Poststroke disposition and associated factors in a population-based study: the Dijon Stroke Registry. Stroke 2012;43:2071-2077.

\section{KARGER}

Fax +41613061234 E-Mail karger@karger.ch www.karger.com
(C) 2012 S. Karger AG, Basel 0251-5350/12/0394-0176\$38.00/0

Accessible online at: www.karger.com/ned
Dr. Yannick Béjot

Dijon Stroke Registry, Department of Neurology, University Hospital

3 , rue du Faubourg Raines

FR-21033 Dijon (France)

E-Mail ybejot@yahoo.fr 